\title{
Critical Analysis on Business Strategies Adopted by an IT Company to Attain Sustainability: Case Study of Cognizant Technology Solutions
}

\author{
Geetha Poornima $\mathbf{K}^{1,2}$ \& Krishna Prasad $\mathbf{K}^{3}$ \\ ${ }^{1}$ Research Scholar College of Computer Science and Information Science, Srinivas \\ University, Mangalore, India \\ ${ }^{2}$ Assistant Professor, Department of Computer Science, St Philomena College Puttur, D.K. \\ India \\ ${ }^{3}$ College of Computer Science and Information Science, Srinivas University, Mangalore, \\ India \\ Email: poornima.sanjay@spcputtur.org
}

Type of the Paper: Explorative Research.

Type of Review: Peer Reviewed.

Indexed In: OpenAIRE.

DOI: http://doi.org/10.5281/zenodo.3510308.

Google Scholar Citation: IJCSBE

\section{How to Cite this Paper:}

Geetha Poornima, K., \& Krishna Prasad, K. (2019). Critical Analysis on Business Strategies Adopted by an IT Company to Attain Sustainability: Case Study of Cognizant Technology Solutions. International Journal of Case Studies in Business, IT, and Education (IJCSBE), 3(2), 14-27. DOI: http://doi.org/10.5281/zenodo.3510308.

International Journal of Case Studies in Business, IT and Education (IJCSBE) A Refereed International Journal of Srinivas University, India.

IFSIJ Journal Impact Factor for 2019-20 = 4.252

(C) With Authors.

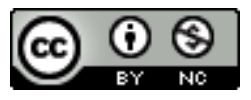

This work is licensed under a Creative Commons Attribution-Non Commercial 4.0 International License subject to proper citation to the publication source of the work.

Disclaimer: The scholarly papers as reviewed and published by the Srinivas Publications (S.P.), India are the views and opinions of their respective authors and are not the views or opinions of the S.P. The S.P. disclaims of any harm or loss caused due to the published content to any party. 


\title{
Critical Analysis on Business Strategies Adopted by an IT Company to Attain Sustainability: Case Study of Cognizant Technology Solutions
}

\author{
Geetha Poornima $\mathrm{K}^{1,2}$ \& Krishna Prasad $\mathrm{K}^{3}$ \\ ${ }^{1}$ Research Scholar College of Computer Science and Information Science, Srinivas \\ University, Mangalore, India \\ ${ }^{2}$ Assistant Professor, Department of Computer Science, St Philomena College Puttur, D.K. \\ India \\ ${ }^{3}$ College of Computer Science and Information Science, Srinivas University, Mangalore, \\ India \\ Email: poornima.sanjay@spcputtur.org
}

\begin{abstract}
Information Technology is a sector that has experienced swift change. Whatever is new today becomes obsolete tomorrow. A company providing Information Technology solutions has to respond quickly to the change in technology. The company has to develop strategies to provide services in emerging technology. The sustainable growth of an IT company depends much on the service areas. The company has to analyze market trends customer requirements and plan accordingly. Cognizant Technology Solutions is a multinational company whose headquarters is in Teaneck, New Jersey, United States. The Company was founded in the year 1994 by Kumar Mahadeva. The major services provided vary from Business and Technology, Consulting, Application Development and Maintenance, IT Infrastructure, Business Intelligence, Data Warehouse, Health Care, Mobile Computing Customer Relationship Management, Supply Chain Management, R\&D Outsourcing and Testing Solutions. To achieve sustainable growth, the company has to set long-term goals, provide necessary skills to the workforce, evaluate its performance against the performance of the competitors and provide the best quality of products/services in cost-effective way. In our paper we have tried to study the business model of Cognizant Technologies, business strategies, measures taken by the company in terms of skill development of its employees, role-based career structure followed, marketing strategy, and Customer retention as steps towards sustainable growth. We also focus on company's contribution towards green initiatives, Corporate Social Responsibilities and SWOC analysis of the company. Finally, we have analyzed Cognizant company's best practices and innovations towards latest digital business such as Internet of things, Data Science, Data Analytics, Artificial Intelligence, Machine Learning, Cloud Computing etc. to consider it as global leader in digital business.
\end{abstract}

Keywords: Cognizant, Business Model, Business Strategy, Customer Retention, Digital Market, Digital Services.

\section{INTRODUCTION :}

Cognizant Technology Solutions Corporation was founded in the year 1994. It is world's prominent professional service oriented multinational organization. Its headquarters is in Teaneck, New Jersey, United States. Its motto is to transform what is envisioned by the clients into a product or service suitable in digital era. The tagline of Cognizant is "Keep changing". Its service areas include banking and insurance, healthcare and life sciences, retail and consumer goods, manufacturing and logistics, travel and hospitality, energy and utilities, communications and media, and technology industries. It was the subsidiary of Dun and Bradstreet and was providing financial solutions to D\&B. This study unveils the growth of the company from a subsidiary to a multi-national in the field of 
Information Technology [1-2]. This paper contains 14 sections. They are 1)Objectives of the study, 2) Milestones of the Company 3) Horizontal and Vertical Growth 4) Business Models, 5) Job Recruitments and Skill Development 6) Significant Clients 7)SWOC Analysis 8)Corporate Social Responsibilities 9) Business Partnership 10) Green Projects 11) Competitors in Digital Market 12) Healthy Practices 13) Rewards and 14) Conclusion.

\section{OBJECTIVES OF THE STUDY :}

The case study to identify measures taken by Cognizant Technology Solutions in sustainable growth is based on the information collected from Company's website and other resources available on the Internet [1-4]. The objectives are :

- To study company's business models

- To learn about employee company's workforce training and development strategies

- To know about the growth of the company in terms of revenues and workforce

- To understand recruitment policies of the company

- To know the organizational structure and operational divisions of the company

- To make use of SWOC analysis for identifying the aspects which require more focus

- To know about the company's competitors and the strategy of the company

\section{MILESTONES OF THE COMPANY :}

Dun \& Bradstreet and Sathyam Computers jointly founded the business during early 1994. It was named as Sathyam Systems Dun and Bradstreet (DBSS). As the inner technology department of Dun \& Bradstreet Company, it aimed on developing large-scale IT projects for companies in Dun \& Bradstreet. It began tracking customers beyond Dun \& Bradstreet from 1996 onwards. DBSS was renamed Cognizant in 1997.

Teaneck, New Jersey of the United States became the headquarters of the company in March 1998 and Kumar Mahadeva became the first CEO. The main focus of the company during those days was on Y2K and Web Technology related projects. In 1998, Cognizant Corporation was divided into two organizations and they were named as IMS Health and Nielsen Media Research. In the same year, the focus of the company got shifted from Y2K related projects to applications management.

In the year 2002, the revenue of the company was $\$ 229$ million. The company started to grow further by taking projects related to maintenance which were rejected by larger IT companies of the time. Cognizant was the company to be assessed by industry-process certifications, such as P-CMM level 5, BS 7799, SEI-CMMi Level 5 [5-6].

In 2003, Lakshmi Narayanan was appointed as the CEO. During his tenure, the service area of the company got widened into Business Process Outsourcing (BPO). Furthermore, the company started to provide its services in the field of business consulting. In the year 2006, Fransico DSouza became the third CEO of the company.

During early 2000s the company started to experience a swift growth rate both horizontally and vertically. In the year 2004, Cognizant was recognized as a leading provider of IT services by Gartner, Forrester, AMR and IDC. In the same year it was added to the prominent NASDAQ 100 Index. In 2006, it got emerged as the fastest global IT service provider to reach $\$ 1$ billion revenue.

The year 2008 happens to an important one in the history of Cognizant as it entered Fortune 1000 with more than $\$ 2.8$ billion revenue. In 2011, the company was enlisted in Fortune 500 with a ranking of 484. By its increased revenue the ranking got improved and is currently at 193 in Fortune 500. From $1^{\text {st }}$ of April 2019, the company is being lead by Brian Humphires in the position of CEO.

Round the globe, the company has 288,200 employees of which more than 150,000 are in India. The company has totally ten centers in India with Chennai being the largest in terms of head count. The other centers include Bangalore, Coimbatore, Gurgaon, Noida, Hyderabad, Kochi, Kolkotta, Mangalore, Mumbai and Pune. There are 166 centers spread across the world. The global delivery centers are located in the UK, Hungary, The Netherlands, Spain, China, Philippines, Canada, Brazil, Argentina, Mexico etc. 
Shifting the focus towards digital business requires lot of changes to be done is company's business strategy. Much effort and investment is needed to train the employees towards its digital journey.

\section{HORIZONTAL AND VERTICAL GROWTH :}

The firm has extended its business over the years beginning with providing financial solutions and projects concerned to Y2K, banking, healthcare and consulting. The growth in terms of revenue and workforce is enlisted in Table-1 [5-7].

Table-1: Growth of the company in terms of workforce and revenue.

\begin{tabular}{|c|c|c|c|}
\hline Year & $\begin{array}{c}\text { Revenue } \\
\text { in Billion US\$ }\end{array}$ & Workforce & $\begin{array}{c}\text { Fortune 500 } \\
\text { Rank }\end{array}$ \\
\hline 2019 & 16.12 & 2,88200 & 193 \\
\hline 2018 & 14.66 & 28,1600 & 195 \\
\hline 2017 & 14.14 & 26,0000 & 205 \\
\hline 2016 & 13.48 & 24,4000 & 230 \\
\hline 2015 & 12.41 & 21,1500 & 288 \\
\hline 2014 & 10.26 & 21,1500 & 308 \\
\hline 2013 & 8.84 & 17,1400 & 352 \\
\hline 2012 & 7.34 & 15,6700 & 398 \\
\hline 2011 & 6.21 & 13,7700 & 484 \\
\hline
\end{tabular}

\subsection{Products/Services Offered}

During early years the company aimed to provide quality solutions to the projects related to Y2K. Early 2000s is considered as the growth period of the company. During this period, it started to open up for providing business solutions. This has become a prominent reason for the increase in growth rate, which was consistently high at that time.

At present, the services offered by the company are broadly categorized as Cognizant Digital Business, Cognizant Digital Operations and Cognizant Digital Systems and Technology [5-6].

The theme of Cognizant Digital Business is "Keep it human." It provides the impression that there is no human intervention when a particular business or service is automated. Cognizant Digital Business, however, is organized so that people are at the core of business service. This type of business works on Digital Maturity Diagnostic framework. Here the customer will conduct quality assessments and check the advancement of the project against its objectives and quality parameters of the industry. This will assist the new business to handle its transformation into digital form. The popular services provided under this category include projects based on Artificial intelligence, Digital; Product Engineering, Digital Strategy, Interactive, Inter of Things, etc.

The motto of Digital Operations is "Make the promise of digital real". The company involves its clients in envisioning the new products. Creative employees along with the help of their R\&D department build the new solutions and the entire business infrastructure of the client is re-engineered quickly and efficiently to thereby increasing the growth in business. The major services offered by the company under this category are Enterprise Services, Industry \& Platform Solutions, Intelligent Process Automation etc.

The motto of Cognizant Digital Systems and Technology is "Modernize your core IT". When running a digital enterprise there will be several hurdles, risks and unforeseen threats. Cognizant will partner with its clients and re-build their code IT infrastructure in a cost-effective way taking care of all possible risks, hurdles and security issues. The major services in this section are Application Services, Cloud Enablement, Cognizant Infrastructure Services, Cognizant Security, Core Modernization, Digital Product Engineering, Enterprise Application Services, Quality Engineering and Assurance etc.

It offers services to a wide range of business sectors including Banking, Healthcare, Communications, Consumer Goods, Education, Capital Markets, Information Services, Insurance, Life Sciences, Manufacturing, Media \& Entertainment, Oil and Gas, Retails, Technology, 
Transportation \& Logistics, Travel \& Hospitality and Utilities, Cognizant provides a wide range of information technology consulting and business processing outsourcing services, including Projectbased application services, Business process services, Business and technology consulting, Complex systems integration, Application outsourcing, IT infrastructure and cloud services, Data Analytics, Business Intelligence, Customer Relationship Management, Data Warehousing, Supply Chain Management, Engineering Management Solutions, ERP Testing Solutions. This stands as the testimony for the growth of the company.

\subsection{Executive Leadership}

Cognizant has a strong leadership team that upholds the ethical values and objectives, takes care of business affairs and decision making. This team will set core values and objectives for the company as per the policies of Corporate Governance.

1.1.1 It includes Brian Humphries as Chief Executive Officer, Karen Mc Lougnlin as Chief Financial Officer, Malcom Frank as President, Cognizant Digital Business, Srinivasan Veeraraghavachary as Chief Operating Officer, Debashis Chatterjee as Executive Vice President and President, Global Delivery, Ramakrishna Prasad Chintamaneni as Executive Vice President and President, Global Industries and Consulting, Matthew Friedrich as Executive Vice President, General Counsel, Chief Corporate Affairs Officer and Secretary, Sumithra Gomatam as Executive Vice President and President, Digital Operations, James Lennox as Executive Vice President, Chief People Officer, Sean Middleton as Senior Vice President and President, Cognizant Accelerator, Issam Allen Shaheen as Executive Vice President, North American Digital Hubs, Dharmendra Kumar Sinha as Executive Vice President and President, Global Client Services and Santosh Thomas as Executive Vice President and President, Global Growth Markets [8].

\subsection{Product Category}

To categorize its products Cognizant uses three-horizon strategy. The products or services offered by the company fall under one or the other category. The categories include Digital Business, Digital operations, Digital Systems and Technology [5]. It has a well defined corporate structure and workforce hierarchy.

\subsection{Acquisitions}

Acquisitions play important role in the growth of a company. The company firmly believes that the performance of the company will increase by collaborating with the business activities of the competitors. When competitor's company is acquired, it eliminates the competition in the field of business and increases the market share. Cognizant started to acquire other companies from the year 2002. [17] The latest acquisition is Zenith Technologies in June 2019. Over the years Cognizant has acquired 56 other companies Table- 1 gives the list of important acquisitions made by Cognizant. The financial deals of acquisitions are not disclosed by the company [9].

Table-2 List of Companies acquired by Cognizant

\begin{tabular}{|l|l|l|l|l|}
\hline SN & Name of the Company & Country & Business & Year \\
\hline 1 & Zenith Technologies & Ireland & Life Sciences Automation & 2019 \\
\hline 2 & Meritsoft & Ireland & Fintech & 2019 \\
\hline 3 & Oy Samlink & Finland & Technology Provider & 2019 \\
\hline 4 & Softvision & USA & Digital Solutions & 2018 \\
\hline 5 & SaaSFocus & Australia & CRM Consulting & 2018 \\
\hline 6 & Hedera Consulting & Belgium & Consulting & 2018 \\
\hline 7 & Bolder Healthcare Solutions & USA & Health Care IT & 2018 \\
\hline 8 & Zone & UK & Digital Agency & 2017 \\
\hline 9 & Netcentric & Switzerland & Digital Marketing & 2017 \\
\hline 10 & Mirabeau BV & Netherlands & Digital Marketing, & 2016 \\
\hline 11 & $\begin{array}{l}\text { UnitedHealthcare Ireland } \\
\text { Limited }\end{array}$ & Ireland & Healthcare & 2002 \\
\hline
\end{tabular}


1) Zenith Technologies: This Company was founded in the year 1998. It is a leading company that develops softwares to ensure supply of vital treatments to patients across the world. It operates across five continents, providing stable and reliable software to top Pharma and Biotech companies [10].

2) Meritsoft: It is a top financial service company founded in the year 2000. It provides customized solutions to cash management, tax management, and cash flow functions between different financial organizations. The products developed by this company are used in world's top most investment banks. Because of the policy, the names of banks and details of transactions are not disclosed. This company is recognized as Deloitte Best Managed Companies in Ireland 2018.

3) Oy Samlink AB: This company offers solutions to financial sector and E-Commerce applications. It has two delivery centers in Finland and several top-level banks are the clients of this company.

4) Softvision: It is an outsourcing company in the field of software development in Romania . It was founded in the year 1998 by Laurențiu Russo and Cristian Motioc. The main service areas of this company include designing and engineering of digital products, transforming existing applications into digital form etc.

5) SaaSFocus: It is an agile consulting company that provides cloud technology services to consulting firms. It was founded in the year 2011. The basic focus of this company is sales force consultancy.

6) Hedera Consulting: This Company provides specialized services in the field of business advisory and data analytics to many industry sectors. Founded in the year 2009, it deals with leading customers across the world in the field of business data analytics.

7) Bolder Healthcare Solutions: Provides financial solutions to groups of hospitals in US. It focuses on cash flow management in the healthcare field. It operates at 15 location in the United States and all the top-level hospitals in the United States are the clients of this company[18].

8) Zone: It provides interactive digital contents to the business firms. It was founded in the year 2000. Headquartered in London, it provides services to brands such as adidas, Aviva, Deutshe Telecom etc.

9) Netcentric: It is a leader in marketing the digital business whose headquarters is in Zurich. It works for leading business brands in Switzerland and provides wide variety of digital solutions to business organizations.

10) Mirabeau BV: it is a digital marketing and customer service agency founded in the year 2001. The specializations of this company include travel and hospitality, financial services B2B sectors etc. The acquisition of this company is Cognizant's step towards expansion of its business across Europe.

11) UnitedHealthcare Ireland Limited: This is the first company acquired by Cognizant in the year 2002. It is an expert in the healthcare industry providing solutions United Healthcare groups comprising of UnitedHealthcare, Uniprise, Ovations, Specialized Care Services and Ingenix.

Cognizant has developed a brand name in the field of healthcare consultancy and financial solutions. Its acquisitions have played key role in building a brand name because of their expertise in their respective domains.

\subsection{Layoffs}

All IT companies follow a strict lay-off strategy. The justification of the companies for this strategy is realignment of business. To control over expenses and redundancies in job, cognizant has slashed hundreds of employees this year. Cognizant follows a strict appraisal strategy. Employees whose performance is marginal are separated from the project. Cognizant claims that the headcount growth is more when compared to revenue growth. To control the overhead expenses, employees with 8+ years of experience who recorded average or below average performance are slashed from the company. 


\section{BUSINESS MODELS :}

Use of a business model plays a key role in the success of Company's business. Developing a business model is more like planning the business itself. Revenue of a company depends much on the business model it follows. Proper business model will mainly focus on the type and quality of services to be provided along with the revenue and cost factors associated with the business. Cognizant is has adopted several customer friendly business models [6]. Some of them are :
1. Two-in-a box model
2. Global delivery model
3. Cognizant unique operating model
4. C-2020 Model
5. Product-Centric Model

\section{1) Two-in-a-Box Model}

This model is also called as "Co-leading model" [5]. In case of complex projects one may not have all the necessary skills to meet the varying needs of the customers. Hence company assigns two leaders for the same project. This is most suitable for offshore projects. Cognizant follows 'focused offshore development policy' all its offshore projects are handled in India. So one leader of the project will be in India and the other one will be his/her offshore counterpart. This model tries to bridge the communication gap between the offshore clients and the developers. When two leaders put their $100 \%$ efforts with all dedication and utmost commitment the outcome will be $200 \%$. The success of this model depends much on the coordination between the two leaders. If they work by complementing each other's strengths and overcoming each other's deficiencies then project will be completed fast. Cognizant expects two leaders to have one voice and are focused on the work they are expected to carry out.

\section{2) Global Delivery Model}

This model is followed by companies offering services related to consultancy. Cognizant uses this business model mainly for its offshore projects. Offshore projects are distributed among different locations to provide uninterrupted services across the globe. When the service providers are globally available, they can respond to customer needs quickly.

This model also ensures that the resources can be accessed in a cost-effective way. Costlier on-shore resources are combined with cheaper offshore resources to provide good service to the customer for a reasonable charge. It also ensures that the company works round the clock ensuring all-time availability of service to its customers [5-6].

\section{3) Digital Operations Solution Model}

This model is used to re-engineer client's business process to improve customer satisfaction, reduce operation cost and increase performance. it adopts emerging technologies such as Artificial Intelligence, IoT and Cloud Computing to re-build clients' business by creating interesting jobs [6].

\section{4) C-2020 Model}

This model contains three different entities involved namely Client Partner, Engagement Partner and Delivery Partner. Combining clients and employees in a project not only bridges the communication gap between the two but also increases the efficiency. When customers and employees become partners business, they too will play an important role in the overall growth of the company. Company scarifies some percentage of its profit for the sake of customers, as it focuses on growth strategy rather than high margin strategy [6].

\section{5) Product-Centric Model}

In this model, the entire structure of the company is refined so as to assign different roles to the workforce in the development of a new product. The role of each employee in the development process is fixed and the entire team will work to develop a product. Compared to project-centric model, in this model, there is continuous interaction with the clients and end-users and the members of the team will gain more expertise as there is no change in the team throughout the development of the product [6]. 


\section{JOB RECRUITMENTS AND SKILL DEVELOPMENT :}

\subsection{Job Recruitment}

Cognizant follows well defined strategy for hiring new graduates for the post of Program Analyst Trainees or Programmer Trainees [11]. Graduates in engineering will be program analyst trainees and BSc, BCA, BCS graduates are recruited for the post of Programmer Trainees. Students with 70 or higher percentage of marks in 10th, 12th and qualifying exams with without backlogs at the moment of interview are eligible for applying. The method of recruitment comprises of consists of

1. Written Test

2. Technical Round

3. HR Round

Written test contains two major sections Aptitude Test and Verbal Ability Test. In aptitude test questions related to mathematical reasoning, current affairs etc will be asked. Verbal ability test is to check the language proficiency of the candidate.

Candidates who clear the aptitude test are eligible for technical interview. There is no strict rule for the way this technical interview is to be carried out. It all depends on the members or interview panel. There may be group discussions and questions on basic computer concepts such as Operating Systems, Database Management, Data Structures, and Programming Languages. Candidates may also be asked to code the puzzles. Once technical interview is completed, then candidate has to face HR interview. To analyze the skills, strengths, weaknesses of the candidate, this round is carried out. It happens to be the final round of the recruitment process.

\subsection{Employee Training Policies}

Cognizant expects every employee to learn about the Policies of the company, the products and services offered by the company and so on. In turn, the employees are asked to share their knowledge with the peers [5][12]. Cognizant firmly believes that if the employee has complete knowledge about the company then only he/she can work better for the same to achieve the goals and objectives set by the company.

The management of the company believes that their business is a knowledge enterprise. It upholds the fact that learning is a continuous process. As a result of this, it creates a full-fledged learning environment and inspires its employees to acquire necessary skills that are much needed for their long-term career in the company. To achieve this, the company has a unique learning program named Cognizant Career Architecture. The company supports role-based career model rather than the traditional designation based career model. There are different career tracks such as Technical career track, Program management career track and Domain career track. This helps the employees to choose a career track that is most suitable for their interest and competence.

There is a complete Cognizant Learning platform which contains syllabus, learning material, exam pattern and certification. Company expects its employees to acquire right skills for the right job. As per the skill-levels, the roles are categorized as Beginner, Learner, Practitioner, Expert and Guru. Every employee starting from the newly recruited one to middle level managers, have to get at least two certifications every year. The training program opted by an employee may be an instructor lead one or on the job training. At the end of the learning period, the employee has to undergo two assessments namely knowledge based assessment and skill based assessment. Knowledge base assessment involves theory exams and skill based assessment involves practical exams. The ultimate goal of the training and certification process is to making the employees of Cognizant ready towards the digital journey.

In addition to this, Cognizant provides special training programs on personality development, soft skills, presentation and communication skills and customer interaction skills. Furthermore, jobs are designed in such a way that every employee is assigned one or other responsibility to make the job more interesting one. Furthermore, there will be job rotation and job enrichment opportunity for the all-round development of the employees.

Digital Engineering, Cloud Computing, Internet of Things, Artificial Intelligence, Data Analysis, Machine Learning, and Deep Learning are the emerging technologies of today. Cognizant expects its employees to gain more proficiency in creating and marketing the product related to these emerging 
technologies. Cognizant Career Architecture helps them build their career so as to make them ready to take up projects related to emerging technology and develop projects more efficiently.

Besides its in-house training programs the company also encourages its workforce to get training from International Training and Certification centers. The company has a tie-up with BSchool for management which offers several customized courses for the Middle-level management. This will enable the employees across the globe to be suitable for the change in scenario in terms of technology or business models.

Initially the company had to invest more to make to train its employee acquire necessary skills. The employees who have undergone this rigor, have performed exceptionally well in their respective fields. The company needs fewer efforts to train them further to make them suitable for the change and advancement in technology.

\section{SIGNIFICANT CLIENTS :}

Cognizant is known for its customer friendly policies [5]. 90\% of its annual revenue is from the loyal customers who renew their agreements with the company. The policy of the company is not to disclose its customer details. The services offered by the company include Healthcare, Insurance, Banking and Financial Services, Manufacturing, Logistics, Energy and Utilities, Retail, Travel and Hospitality, Information Media and Entertainment, Technology and Communications.

- All the top 30 pharmaceutical companies, 16 of the top 20 U.S. healthcare plans, 3 leading U. S PBM industries, 12 of the top 15 medical device firms are taking Cognizant's healthcare ser vices.This is the clear proof of the healthcare consultancy knowledge of the company.

- In banking, 17 of top 20 North American Financial institutions and all the European Banks are the client partners of Cognizant.

- In Insurance sector, among the top 10 Global Insurances 7 are the clients of Cognizant. 33 among 50 US insurance companies are taking Cognizant's services in the field of Insurance consultancy.

- In Manufacturing, Logistics, Energy and Utilities sector 7 of top 10 American Original Equipment Manufacturing companies , 8 of top 15 industrial manufacturers, 5 of top 15 chemical manufacturers, 5 of top 15 utilities in Na, 5 of top 10 Electric utilities in Europe, 4 of top 6 Oil and Gas super majors are the clients of Cognizant.

- 9 of the top 30 Global Retailers, 3 of the leading US Airlines, 3 of the World's leading Restaurant Chains and 2 of the top 4 Global Distribution System companies take the services of Cognizant in Retail, Travel and Hospitality sector.

- In the field of Information Media and Entertainment the prominent clients of Cognizant include 10 of top 10 Global Media Companies, 4 of top 6 major US movie studios, 5 of top 10 information services and 13 of top 15 publishers.

- Technology and Communications sectors 4 of top 5 OEMs, 5 of top 10 information service providers across the world, 7 of top 10 Communications Service Providers and Equipment Venders and top 3 Cable providers are the client partners of Cognizant Technology Solutions.

\section{SWOC ANALYSIS :}

The purpose of SWOC analysis is to understand the strengths, weaknesses, opportunities and challenges of the company in the field of Business [13-14]. Cognizant Technology Solutions is a US based multinational service provider company that provides IT services in Healthcare, Insurance, Banking and Financial Services, Manufacturing, Logistics, Energy and Utilities, Retail, Travel and Hospitality, Information Media and Entertainment, Technology and Communications.

Strengths

1. Customer friendly nature: All business models and the strategies of the company are client friendly in nature[.

2. Focused digital technology and innovation: The Company's three horizon strategy is very much useful to focus the development of IT solutions. 
3. Friendly environment for the workforce: The Company is regarded as employee friendly one which provides ample opportunities to enhance the skills of the employees. It also involves the workforce in its corporate strategy and community development.

4. Highly skilled workforce: Top-level managements are recruited from IITs IIMs and similar institutions across the world. Skill development policies of the company make every employee to acquire right skills for the right job.

5. Well defined disaster recovery model: The Company provides a well structured disaster recovery plan. If the project is to be delivered from the Chennai centre and there is flood in Chennai, then the same project will be delivers from nearest centre without charging extra on its clients.

6. Cost effective services: The main focus of the company is Speed of Service (SoS). When quality business solutions are created by taking less time, the services will always be cost effective

7. Big data and Cloud Computing: The company is ahead in big data capabilities and cloud computing technologies compared to peers or competitors

8. Branded for Healthcare and Financial Consultancy: The Company has established a brand name in the field of Healthcare and Consultancy. The big list of clients in this field stands the testimony for this.

9. Round the clock availability of Services: Being a multinational company, its branches are spread all over the world. It provides services round the clock as it follows Global Delivery Model.

Weakness

1. More focus to North America Markets: Most of the clients are from North America. When the focus of the company is limited to one geographical area, it directly affects to the growth of the company.

2. Limited depth in Infrastructure management: Though company provides services in almost all fields of business, it lacks expertise in Infrastructure and management field. If more focus is given to this field, it can attract wide range of customers.

3. High investment on training the employees: The Company trains every employee starting from newly recruited ones to middle level managers. Training will become a overhead if the employees do not perform up to the mark after

\section{Opportunities}

1. To accept projects related to Government: Major clients of the company are from private sectors. In developing countries, there is a lot of scope for catching hold of Government projects as all Government projects are

2. Concentrate more on the European market: In the emerging technologies the Company has to focus more on European Markets.

3. Explore more avenues in Service and Healthcare sectors: Exploring new avenues in the field of expertise will always become the main reason for the growth of any company.

4. Acquire more competitors in the global market: When more and more competitors are acquired, their expertise and markets will also become the assets of the company there by increasing the growth.

5. Take up more projects in emerging technologies: Digital market has observed rapid growth over in past few years. There are several emerging technologies in the field of IT that are to be focused more.

6. Focus more on potential customers: For the sustainable growth and development, the company has to widen its market. Hence it has to find strategy for its potential customers.

7. Integration of existing business with emerging technologies: The existing decision making strategies can be automated by applying Artificial Intelligence techniques to make decision making more effective one.

Challenges

1. Tough competition in the global market: The Company has to compete with several wellestablished multi-national companies such as Tata Consultancy Services, Infosys, Wipro, Accenture and so on. 
2. Stringent Government policies in case of outsourcing: Government has enforced strict policies on outsourcing. Munch of Cognizant's business is in the field of outsourcing. When government enforces strict policies,

3. Increase in inflation in developing countries: In developing counties like India, there is high inflation rate. This will have a direct impact on the revenue of the company.

4. Increase in wages and decrease in profitability: Information Technology is a field where the wages of employees are more as most of the work is to be carried out manually[13-15].

\section{CORPORATE SOCIAL RESPONSIBILITIES :}

A company's initiatives towards the development of downtrodden or underprivileged also plays as key factor in its growth [18]. For this purpose, Cognizant Foundation was established. It works in association with several NGOs such as Development of Humane Action (DHAN), Self Help Groups and Hand in Hand (HIH India)[17]. It has launched a unique program called Rebuilding Communities Program (RCP) for the rehabilitation of people affected by natural calamities. Cognizant's CSR focuses on the following fields:

- Education: Cognizant's employees volunteer during weekends, conduct classes to students of rural schools. In India, Cognizant Foundation has been working on different projects to provide quality education to underprivileged students.

It had identified 160 different schools in rural areas and provided IT infrastructure. The volunteers of Cognizant Foundation prepare syllabus and educate teachers in the field of Information Technology. It also provides scholarships for the less-privileged students.

- Outreach and Skill Development Programs: Volunteers of Cognizant Foundation conduct number of activities such as awareness programs on health and hygiene, Nutrition, solid waste management are some of the outreach programs organized by Cognizant Foundation. It also organizes number of skill development programs such as beautician course, fashion designing course, cell phone servicing, and four wheeler driving course for the benefit of economically backward communities.

- Healthcare: Providing advanced Heart treatment to the poor and needy, providing artificial limbs for the differently abled, setting up of mobile Eye care units for visually impaired people, sponsoring dialysis treatment for the downtrodden are some of the programs organized by Cognizant Foundation for the benefit of society.

- Community Development: Re-construction of damaged schools, rehabilitation of people who were affected by exceptional rain in Chennai, rehabilitation of differently abled children, women empowerment programs organized by Cognizant Foundation come under this category.

\section{BUSINESS PARTNERSHIPS :}

There are more than 60 IT companies are the business partners or strategic partners of Cognizant [6]. Some of them include:

- AWS Technology: Amazon Web Services is a company that provides cloud platform to business organizations. Cognizant's expertise in consultancy and AWS Technology's expertise in Cloud platform services combine to form effective and efficient business. Cognizant is referring AWS as its strategic partner.

- HP: HP is strong in technology and Cognizant is strong in Consultancy. These two companies combine to develop quality products in infrastructure, testing and security. Most of the testing tools used by Cognizant's clients and end-users are developed by HP.

- Adobe: Adobe's expertise in cloud-based marketing, advertising and Cognizant's expertise in business consultancy are combined to provide best quality digital services to meet wide range of customers.

- CISCO: The powerful technologies of CISCO and top-class services of Cognizant are joined to provide companies that require several technology-based services. 
- CLOUDERA: This Company has several certified consultants with the help of whom Cognizant creates top-quality business solutions for its customers across the globe.

- CYBERARK: Cognizant's proficiency in the field of business consultancy and Cyberark's knowledge in data security combine to produce secure accounting solutions.

- IBM: Management skills of Cognizant are integrates with IBM to provide services related to business data analytics.

- Hitachi: From the year 2012, Cognizant is partnering with Hitachi Vantara to provide high security solutions to manage clients' data.

- Oracle: More than 250 cloud-based projects are undertaken by Cognizant in association with Oracle.

- Dell: Dell Technologies and Cognizant combine to provide best possible solutions involving networking, cloud and security.

\section{GREEN PROJECTS :}

The company is bound to uphold its vision statement to preserve natural resources [6] [20]. The green initiatives taken by the company include

- $\quad$ Planting of trees.

- Limited usage of natural resources

- Recycling of water

- Energy conservation

- Rainwater harvesting

- Avoiding the use of plastic cups, use and throw plates and paper cups on the campus

- Effective ways of solid waste management

\section{COMPETITORS IN DIGITAL MARKET :}

Being multinational company it faces tough competitions in the global digital market from IT giants such as Infosys Limited, Wipro Limited, Accenture, HCL Technologies, Tata Consultancy Services, IBM Global Solutions, CGI, Tech Mahindra, Larsen \& Toubro InfoTech, Insight, Capgemini etc. Because of its customer centric business model, creative workforce, accelerated quality of service (QoS) and Cost effectiveness, it is considered as one of the most admired IT company in the world [5-6].

The company's plans towards establishment of brand name include the following [5]:

- Sponsoring business and sports events: Cognizant had sponsored several International summits in the field of business and emerging technologies. In addition to this, the Company had organized an International Hockey event organized by associates of World Hockey Federation.

- Workforce engagement: The Company organizes several events inside and outside for building a strong relationship with its workforce other than Corporate Social Responsibilities. The activities sponsored by Cognizant in this line include Day out in Zoo, Day out in a Picnic spot etc. They not only build good relationship between employees but also play key role establishment of brand name in the community.

- Family and friends offer: Employees can refer their family members or friends who have necessary skills for the jobs. This will help in grabbing the best talent available. The company organizes number of activities to involve the co-workers and family members. These activities include "Food and Fun Day”, "Family and Friends Day” etc. This will help to bring the three focal points in one place which in turn can be used for talent hunt activity.

- Helping the community: The employees join hands with the NGOs or non-profit organizations and participate in activities such as "Day with soldiers" , "Pet drives" "Food drives" etc. Combining employees, family, friends and community is a good business strategy of the company. 


\section{HEALTHY PRACTICES :}

- "Focused Offshore Development Company" [5]: All the offshore centers are being operated From India. Cognizant calls them as Global In-house Centers or GICs. This has considerably reduced the cost of development and maintenance and increased the revenue.

- "Engage customers to build the growth": [5] Cognizant treats its customers as partners. Customers who bring business are called as client partners and the company involves them in its business. Some percentage of revenue generated will be given to the clients. This way it also helps in the growth of its customers.

- "Three horizon strategy": To increase the focus of service and revenue, the entire business is divided into three horizons namely Cognizant Digital Business, Cognizant Digital Operations and Cognizant Digital Systems and Technology [5]. This has given a positive result and the company has reached its expected target.

\section{REWARDS :}

- Cognizant is ranked 193 on the Fortune 500 in the year 2019.

- In the year 2019, the company received IBM's beacon award for its outstanding services in the field of hybrid cloud solutions.

- It is ranked at 16 in Barron's 100 Most Sustainable Companies for the year 2018,

- It is at $17^{\text {th }}$ place on Fortune 50 , at $18^{\text {th }}$ place on the Fast Tech 25 by Forbes

- It is awarded as Forbes' Best Employers for Women in the year 2018.

- It is regarded as Fortune's one of the most admired companies from the past 11 years.

- It is named as a leader in services like Application Testing, Application Modernization and Artificial Intelligence by Gartner

- It is ranked among the Top 3 employers in the software industry by IDC with a higher ranking based on several key parameters such as employee satisfaction index, job satisfaction and career development, compensation and benefits [5-6]

\section{CONCLUSION :}

Over the years Cognizant has re-structured itself several times. It has changed its focus from providing technology solutions to business firms to providing solutions in emerging technologies. It stands the first in responding positively to changing technologies. In the field of Information Technology, whatever new today becomes obsolete very fast. Responding positively to change in technology, widening the business to emerging technologies are the reasons for the growth of the company. The company that provides services in the field of Information Technology has to change its strategy, products and try to respond to the current trends and needs of the customers. The success of any company in general and an IT company in particular depends much on how it responds to the change and advancement in technology. Being a Multinational company, it has spread the services round the globe. In the beginning Cognizant Technology Solutions was providing services to the customers in the field of healthcare and business. At present it is providing services in new technologies such as Artificial Intelligence, Machine Learning, Cloud Computing and Internet of Things. Company's Employee training strategies, Flexibility, Diversified business sectors, Employee retention policies, Customer Retention Policies, strategic partnership with experts in the relevant field, efforts towards green initiatives and Corporate Social Responsibilities are the testimonies for the success of the company.

\section{REFERENCES :}

[1] Aithal, P. (2017). Industry Analysis-The First Step in Business Management Scholarly Research. International Journal of Case Studies in Business, 1(2), 1-13. https://doi.org/10.5281/zenodo. 810347

[2] Zaidah, Z., \& Zainal, Z. (2007). Case study as a research method. Jurnal Kemanusiaan, 9(Journal Article), 1-6. https://doi.org/10.1177/15222302004003007 
[3] Aithal, P. S., (2016). Study on ABCD Analysis Technique for Business Models, business strategies, Operating Concepts \& Business Systems, International Journal in Management and Social Science, 4(1), 98-115. DOI : http://doi.org/10.5281/zenodo.161137

[4] Madhushree., Revathi, R., Anil Kumar, \& Aithal, P. S. (2018). Business Strategy of Top Indian IT Company: MindTree. International Journal of Case Studies in Business, IT and Education (IJCSBE), 2(1), 22-36. DOI: http://dx.doi.org/10.5281/zenodo.1249871

[5] Wikipedia. Retrieved from https://en.wikipedia.org/ wiki/Cognizant/ on 05/08/2019

[6] Cognizant Deutschland, IT Consulting, Business Process Services, Digital Transformation. Retrieved from https://www.cognizant.com/ on 18/08/2019

[7] Number of Employees At Cognizant 2008-2018, Statista. Statista. Retrieved from https://www.statista.com/statistics/328322/cognizant-employee-numbers/ on 05/08/2019.

[8] Senior Management-Executive Leadership Team, Cognizant. Retrieved from https://www.cognizant.com/about-cognizant/executive-leadership on 10/08/2019.

[9] Retrieved from https://www.crunchbase.com/search/ acquisitions/field/organizations/ num acquisitions/cognizant-technology-solutions on 06/08/2019,

[10] Eccles, Robert G., David Lane, and Prabakar PK Kothandaraman. Cognizant Technology Solutions. Harvard Business School Case 408-099(2011).

[11] Cognizant Recruitment Process - GeeksforGeeks. GeeksforGeeks. Retrieved from https://www.geeksforgeeks.org/cognizant-recruitment-process/ on 04/08/2019.

[12] Commitment To Talent Development Excellence. Main. Retrieved from https://www.td.org/ magazines/td-magazine/commitment-to-talent-development-excellence on 18/08/2019.

[13] Aithal, P. S. and Suresh Kumar, P. M. (2015). Applying SWOC Analysis to an Institution of Higher Education. International Journal of Management, IT and Engineering (IJMIE), 5(7), 231-247. DOI :http://doi.org/10.5281/zenodo.163425.

[14] Aithal, P. S., (2016). Study on ABCD Analysis Technique for Business Models, Business Strategies, Operating Concepts \& Business Systems. International Journal in Management and Social Science, 4(1), 98-115. DOI :http://doi.org/10.5281/ zenodo.161137.

[15] Commitment To Talent Development Excellence. Main. Retrieved from https://www.td.org/ magazines/td-magazine/commitment-to-talent-development-excellence on 18/09/2019,

[16] Cognizant SWOT \& PESTLE Analysis - SWOT \& PESTLE.com. SWOT \& PESTLE.com. Retrieved from https://www.swotandpestle.com/ cognizant/ on 08/08/2019

[17] Thomas Andre., (2014). Corporate Social Responsibility Boosts Value Creation at the Base of the Pyramid. Cahier de recherché,11, 10-20. Retrieved from https://hal.archivesouvertes.fr/hal-00989791.

[18] Social-alleviating Disparities in Education: Cognizant. Retrieved from https://www.cognizant.com/about-cognizant/sustainability/social\#panelvt5 on 06/06/2019

[19] Retrieved from https://www.cognizant.com/whitepapers/17-must-do-s-to-create-a-productcentric-it-organization-codex4674.pdf on 17/09/2019,

[20] Corporate Environmental Stewardship Cognizant. Retrieved from https://www.cognizant.com/ about-cognizant/sustainability/environmental- stewardship on 08/08/2019. 